\title{
Benefits of forest legislation enforcement on the Status of Onigambari Forest Reserve
}

\author{
Kolade, R.I. ${ }^{1}$, Adejumo, A.A. ${ }^{2}$, Oke, D.O. ${ }^{1}$ and Ogunsola, A.J. ${ }^{1}$
}

${ }^{1}$ Forestry Research Institute of Nigeria, Headquarters, Ibadan.

${ }^{2}$ Federal College of Forestry, Forestry Research Institute of Nigeria, Ibadan.

Corresponding Author: E-mail: kolade_ibukun@yahoo.com

\begin{abstract}
Forest legislation enforcement is a fundamental strategy needed for the regulation of use and development of forest reserves. Effective law enforcement is necessary for continued production of goods and services. However, gaps have been noticed in the forest legislations' enforcement in the study area. Simple random sampling was used to select 93 forest dwellers from 3 purposively selected adjoining communities in Onigambari forest reserve: Onigambari (28), Busogboro (38) and Onipe (27). Samples were drawn in proportionate to sizes. A set of questionnaire was used to obtain data on factors responsible for weakness in enforcement of forest legislations and various benefits being derived by the host community dwellers from the use of forest reserve irrespective of the existence of forest legislations. Data were analyzed using descriptive statistics and logit regression at $\alpha_{0.05}$. Respondents were $42 \pm 13.7$ years, mostly male (75.9\%) and married (81.9\%). The identified factors responsible for weakness in enforcement of forest legislations included low activities of extension agents (77\%) and lack of effective supervision by the representatives of the State governments (Managers). Benefits being derived by the forest dwellers were achievement of sustainable forest production, employment generation and attention to road network with odd-ratios, 62.18, 2.10 and 1.70 respectively. The study substantiate the existence of weakness in enforcement of forest legislations in Onigambari forest reserve and also revealed an array of benefits being derived by the forest dwellers. Therefore for continuity and improvement in the goods and services provided by the reserve, it is necessary for the government to build institutional capacity so as to fostering better enforcement of forest legislations and compliance.
\end{abstract}

Keywords - Law enforcement, Weak enforcement, Forest benefits, Forest dwellers.

\section{INTRODUCTION}

Policy is the basis for which legislation is needed to regulate the use and development of forest resources, while law enforcement is an integral part of the overall management of the National Forest System. Law enforcement personnel, line officers, and appropriate staff ensure that prevention, investigation, enforcement, and programme management requirements are fully integrated into all National Forest System resource management programmes. Law enforcement personnel operate as full partners within the forest service organization in carrying out the agency's mission, especially in upholding federal laws and regulations that protect natural resources, agency employees, and the public. Accomplishment of the forest service law enforcement mission is a product of trust, co-operation, and collaboration between law enforcement personnel and other agency employees (USDA, 2015).
FAO (2010) reported that every year, a significant proportion of the world's timber is harvested, transported, processed and traded in violation of national laws. Illegal logging and associated timber trade have far reaching environmental, social and economic consequences, including loss of biodiversity and habitants, political instability, increased income disparities and market distortions. While accurate data on the scope of illegal forest activities is not available, the World Bank estimates that losses from illegal logging in terms of global market value are more than US\$10 billion annually and lost government revenues total about US\$5billion. The magnitude of the problem has prompted governments, with the help of international and nongovernmental organizations as well as the private sector, to step up their analysis of the socio-economic causes and consequences of illegal logging. Studies have shown that issues to be resolved include (i) Flawed policy and legal frameworks (ii) Uncertainty surrounding forest tenure (iii) 
Weak law enforcement; insufficient information on the forest resources, coupled with increased demand for forest resources (iv) Corruption and lack of transparency. Several processes are therefore underway at international, regional and national levels to combat forest crime and improve compliance.

Effective policies (legal reform) require an assessment of other capacity and willingness of government and others to implement new legal strategies, a commitment to monitoring the effects of legal strategies, a commitment to monitoring the effects of legal changes over time and a responsiveness to the result of the monitoring.

One of the factors that militate against sustainable forest management is the absence of a National Forestry Act. Apart from using the provision of the Act to regulate forestry practices in Nigeria and to give also a legal backing for the National Forest Policy, it would further enable us to meet the obligations on the treaties and conventions relevant to forestry development to which Nigeria is a signatory. The first ever National Forestry Act has also been evolved to back the policy which has been passed to council for approval though it is yet to see the light of the day.

Conclusively, there are lot of benefits from enforcement of forest legislation for both the host communities and the manager of forest reserves (Government). Some of these benefits are pointer to the existence of economic well-being of the forest dwellers. That is why the importance of community participation cannot be ruled out in effective management of forest reserves, while one of the benefits of community participation in forest management is the improvement in socio-economic well- being of the people (Banjo and Abu, 2014).

Hence, this paper addressed the weakness in enforcement of forest legislation and also identified various benefits derived by the host community dwellers from the use of the forest irrespective of the existence of forest legislations.

\section{METHODOLOGY}

\section{Study Area}

Onigambari forest reserve was declared to be Ibadan forest reserve by a resolution of Ibadan council on $14^{\text {th }}$ September 1899 and take its name from a nearby village called Onigambari. The reserve is located on latitude $7^{0} 25^{1}$ and
$7^{0} 55^{1} \mathrm{~N}$, and longitude $3^{0} 53^{1}$ and $3^{0} 9^{1} \mathrm{E}$ located in the Oluyole local government of Oyo State, Nigeria (Fig. 1). The forest reserve, which used to be part of the lowland rainforest, is now in the Guinea savanna and Derived savanna zones. It covers a total land area of 13932.18 hectares consisting of five zones: Mamu, Onigambari, Busogboro, Odo-Ona, Onipe and Alabata. The Mamu and Onigambari zones were predominantly made up of Gmelina plantations. The topography is generally undulating, lying at altitude between $120-150 \mathrm{~m}$ above sea level and the area is bounded by two Rivers (Rivers Ona and Awon). Mean annual rainfall ranges between $1200 \mathrm{~mm}$ to $1300 \mathrm{~mm}$ with two distinct wet seasons.

\section{Sampling Techniques and Data Analysis}

Purposive sampling was used to select three villages among the adjoining communities in Onigambari forest reserve (Within $1-3 \mathrm{~km}$ radius) and these include: Onigambari, Onipe and Busogboro with the projected population of 1,428, 1271 and 1,018 respectively. Diaw et al., (2002) was therefore adapted to sample from the population. Hence, 10\% sampling intensity was used to randomly sample respondents in the communities where their population is less than 500, $5 \%$ for between 500 and 1000 , and $2.5 \%$ for over 1000 .

Therefore, 28 respondents were reached in Onigambari, 38 in Busogboro and 27 in Onipe, totaling 93 respondents that were sampled for the study. Hence, 93 structured questionnaires were administered for primary data collection while 83 were retrieved. The returns represent $89 \%$ of the total number of questionnaire administered to the forest dwellers in the study area. Data were analyzed using descriptive statistics and inferential statistics (Logit regression analysis).

\section{Population Projection}

The current sampled communities' population was projected from 1991 communities' census report to 2019 using the formula below.

$\mathrm{P}_{\mathrm{n}}=\mathrm{P}_{\mathrm{o}} \mathrm{e}^{\mathrm{rt}}$------(1)

Where: $P_{n}=$ Final population

$\mathrm{P}_{\mathrm{o}}=$ Initial population i.e 1991

$\mathrm{e}=$ Exponential

$r=$ Growth rate (Average of 3.5\%)

$\mathrm{t}=$ Time interval $(\mathrm{x}-1991) \mathrm{yr}(\mathrm{s})$ 


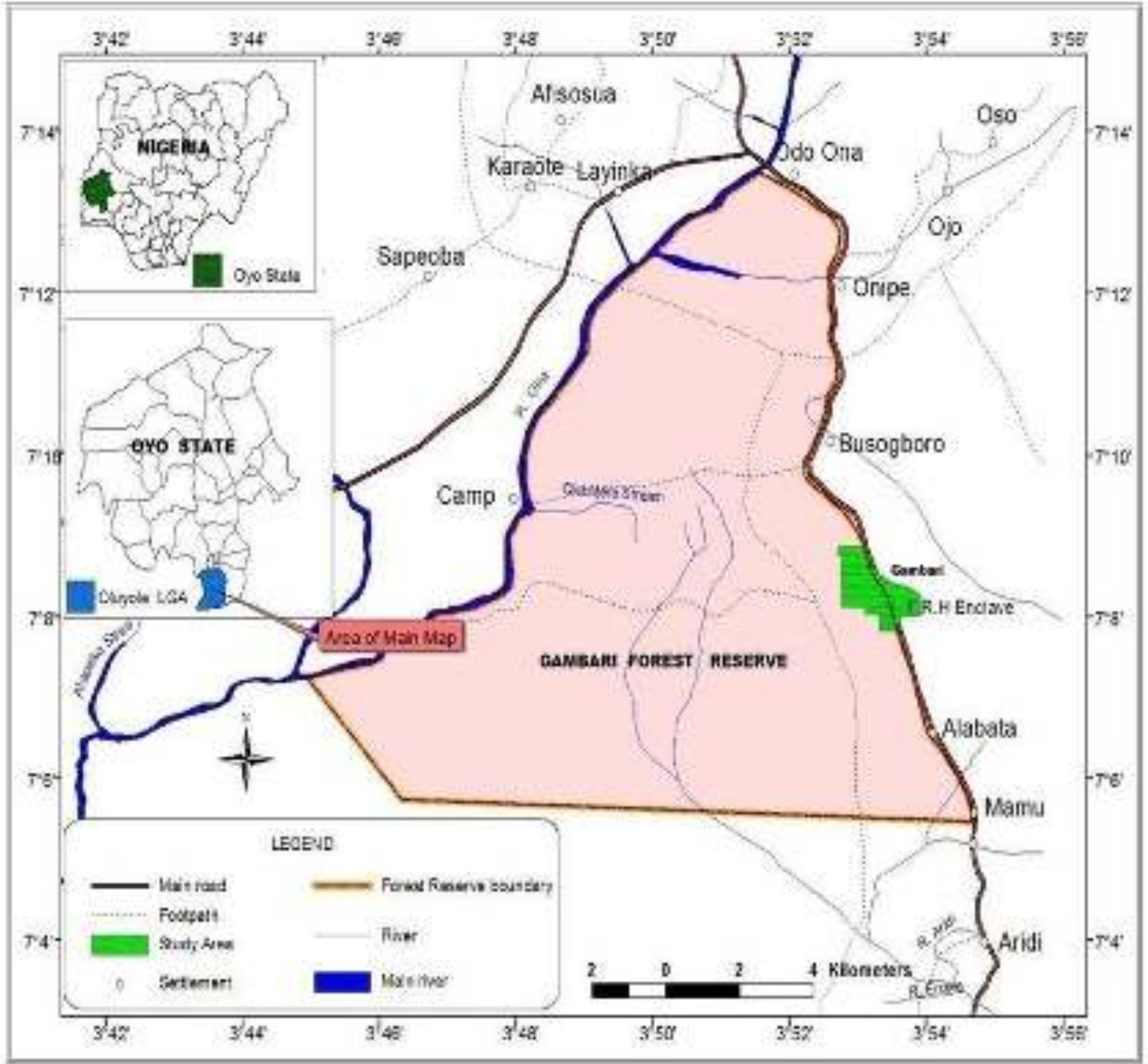

Fig 1: Map of Onigambari Forest Reserve showing the Forest Adjoining Communities

\section{Logistic regression}

The binary logistic models are useful in a situation whereby the dependent or response variable is binary in nature. This implies that they can have only two possible values. The models therefore describe the relationship between one or more continuous independent variable (s) to the binary dependent variable.

The two common binary models are the logit and probit. The logistic model is particularly preferred because of the unique information it provides. Distinct information provided by logit is the odds ratio. It is defined as the ratio of the odds of an event occurring in the group to the odds ratio of it occurring in another goup (Deeks, 1996 and Davies, 1998). The logistic model of a response $p$ between 0 and 1 is given as:

$\operatorname{Logit}(\mathrm{p})=\log (\mathrm{p} / 1-\mathrm{p})=\log (\mathrm{p})-\log (1-\mathrm{p})$
The simplest form of logistic model is expressed as:

Logit $(p i)=a+b x 1+-------+b x 4$

Where:

$\mathrm{Pi}$ = Probability of significance of benefits derived from Onigambari forest reserve (Dependent variable)

$\mathrm{Xi}=$ Vector of predictor or independent variables $\mathrm{a}$ and $\mathrm{b}=$ regression parameters.

The independent variables are:

$\mathrm{X}_{1}=$ dummy variable indicating whether Attention to Road Network (ARN) has been a benefit being derived from the existence of the forest reserve.

$\mathrm{X}_{2}=$ dummy variable indicating whether Establishment of Industry (EIND) has been a benefit being derived from the existence of the forest reserve. 
$\mathrm{X}_{3}=$ dummy variable indicating whether Rural Electrification (REL) has been a benefit being derived from the existence of the forest reserve.

$\mathrm{X}_{4}=$ dummy variable indicating whether Efficient Forest Administration (EFA) has been a benefit being derived from existence of the forest reserve.

$\mathrm{X}_{5}=$ dummy variable indicating whether Recruitment for Regular Inventory by the government (RRI) has been a benefit being derived from existence of the forest reserve.

$\mathrm{X}_{6}=$ dummy variable indicating whether Stem down of Rural-Urban Migration (SRUM) has been a benefit being derived from existence of the forest reserve.

$\mathrm{X}_{7}=$ dummy variable indicating whether Enhancement of Economic Growth (EEG) has been a benefit being derived from existence of the forest reserve.

$\mathrm{X}_{8}=$ dummy variable indicating whether Employment Generation (EG) has been a benefit being derived from existence of the forest reserve.

$\mathrm{X}_{9}=$ dummy variable indicating whether More Land Under Cover (MLUC) has been a benefit being derived from existence of the forest reserve.

$\mathrm{X}_{10}=$ dummy variable indicating whether Achievement of Sustainable Forest Production (ASFP) has been a benefit derived from existence of the forest reserve.

$\mathrm{X}_{11}=$ dummy variable indicating whether Increase in Income Propensity of the dwellers (IIP) has been a benefit derived from existence of the forest reserve.

$\mathrm{X}_{12}=$ dummy variable indicating whether access to Raw Materials for Industries (RMI) has been a benefit derived from existence of the forest reserve.

\section{DISCUSSION}

Table 1 showed the socio-economic characteristics of the respondents in the study area. Information on gender revealed that $75.9 \%$ of the respondents were male while $24.1 \%$ were female. The average age of the respondents was $42 \pm 13.7$ years. It could be inferred that the size of the economically active population engaged in forest and other related activities is presently high and this agrees with the findings of (Faleyimu, 2010). The implication for this could probably be tied to the fact that forestry sector serves as easier way to satisfy the basic needs of life (Food, Shelter and Clothing). Poor or weak forest legislation enforcement may therefore pose a lot of danger to the world's clamour for effective conservation to ensure sustainability of forest resources.

Among the 83 respondents, the result revealed that $81.93 \%$ were married. This implies that majority of the forest dwellers are married and thereby, involving in the forest livelihood activities which cater for their household needs. This finding concurs with the research work of Akinbile (2007) that marriage confers responsibility.

In terms of educational status of the respondents, majority of them had secondary $(31.3 \%)$ and primary $(34.9 \%)$ education. This could be attributed to the influence of the environment on the forest dwellers. Only few who are determined to study further leaves such environment. Many often do not care to study further inasmuch they start making money at a very tender age. This agrees with (Adejumo, 2016).

As touching the occupation of the respondents, majority of them were farmers $(47.0 \%)$ and artisans $(32.5 \%)$ and these are the predominant occupation in such environment since they are majorly concerned about how to cater for their families and not in pursuit of living a luxury life.

Also, the study revealed that most of the respondents (73.5\%) are native of the study area while only few of them (20.5\%) must have settled in the area many years ago in search of opportunity for subsistence farming. This uphold the report of Calibre and SCC (2000) which reported that the people living in and around the forests include smallholders practicing subsistence farming and settlers who have come in the areas to search for new opportunity in agriculture.

Table 1: Socio-economic Characteristics of the Respondents in the Study Area

\begin{tabular}{lll}
\hline $\begin{array}{l}\text { Socio-economic } \\
\text { Characteristics }\end{array}$ & Frequency & Percentage (\%) \\
\hline Gender & & \\
Male & 63 & 75.9 \\
Female & 20 & 24.1 \\
Total & 83 & 100 \\
Age (Years) & & \\
$21-30$ & 18 & 21.7 \\
$31-40$ & 26 & 31.3 \\
$41-50$ & 22 & 26.5 \\
$51-60$ & - & - \\
$61-70$ & 17 & 20.5 \\
Total & 83 & 100 \\
Marital Status & & \\
Single & 68 & 81.9 \\
Married & 12 & 14.5 \\
Widow & 3 & 3.61 \\
Educational Status & & \\
No formal education & 26 & 31.3 \\
Primary & 26 & 31.3 \\
\hline
\end{tabular}




\begin{tabular}{|c|c|c|c|}
\hline \multicolumn{2}{|l|}{ Secondary } & 29 & 34.9 \\
\hline \multicolumn{2}{|l|}{ Tertiary } & 2 & 2.4 \\
\hline \multicolumn{2}{|l|}{ Total } & 83 & 100 \\
\hline \multicolumn{4}{|l|}{ Occupation } \\
\hline \multicolumn{2}{|l|}{ Artisan } & 27 & 32.5 \\
\hline \multicolumn{2}{|l|}{ Farming } & 39 & 47.0 \\
\hline \multicolumn{2}{|l|}{ Trading } & 17 & 20.5 \\
\hline \multirow{2}{*}{\multicolumn{4}{|c|}{$\begin{array}{l}\text { Total } \\
\text { Nativity }\end{array}$}} \\
\hline & & & \\
\hline \multicolumn{4}{|l|}{ Within the } \\
\hline \multicolumn{4}{|l|}{ Area } \\
\hline Total & & 83 & 100 \\
\hline
\end{tabular}

Source: Field Survey, 2019.

\section{Weakness in Enforcement of Forest Legislation}

Table 2 showed the respondents' responses to the reasons for weakness in enforcement of forest legislation in the study area. It was evident that low activities of extension agents $(77.1 \%)$ and lack of effective supervision by the representatives of the State government $(77.1 \%)$ were the major factors responsible for weakness in enforcement of forest legislation in the area. Truly, it is so obvious that forestry extension agents are not sufficient as it ought to have been compared with what is obtainable in the agricultural sector. One could easily identify agricultural extension agents who monitor agricultural activities and at the same time provide useful information on new ideas. Through this medium, farmers are more sensitized and are also advised to do the right thing that would boost their yield.

Either consciously or unconsciously, agricultural extension agents participate in enforcement of valuable agricultural legislations, which would improve the performance of the sector. As a matter of fact, diverse agricultural research institutes have been established by the Federal government to research into different areas of agriculture. The case is different in forestry. Forestry has only one research institute in Nigeria (Forestry Research Institute of Nigeria), so the task of forest extension has been left for them. It is necessary to stress that Forestry Research Institute of Nigeria has been doing wonderfully well in the dissemination of forestry innovations to farmers and environmentalists. Precisely, her Department of Forest Economics and Extension has been going out on fortnight basis to educate farmers on the new ideas in forestry and how agroforestry would help them to maximizing the use of land.

However, the role of forestry extension agents in enforcement of forest legislation cannot be over-emphasized as they could also assist in educating the farmers or forest dwellers on the importance of forest policies and its benefits. As responses by the respondents also showed that lack of effective supervision is another factor responsible for weakness of forest legislation's enforcement, it is important to stress that success in any project evaluation is highly depended on the manager's capability of supervision, coordination and control. Meanwhile, the long-term fortunes of forestry depend largely on the institutions put in place as well as the performance of the managers (Adeyoju, 2001). This is also supported by Faleyimu (2010) which stated that irrespective of the sustainability strategy and the enabling environment, the human role is indispensable. Also accountability and transparency are important components of effective supervision and co-ordination.

Other prominent factors responsible for weakness in enforcement of forest legislation were low income earning of the rural dwellers $(67.5 \%)$ and characterized illiteracy level of the forest dwellers (65.1\%) There is an adage which says "A hungry man is an angry man", therefore forest dwellers with low income capability tends to violate government laws so as to meet his or her urgent immediate need. For instance, various policies placed on firewood extraction may not be perfectly enforced while huge success in this regards may be extremely difficult. Prevalent illiteracy level of the forest dwellers required periodical sensitization by the forestry extension agents so as to ensure strict compliance.

Table 2: Weakness in Enforcement of Forest Legislation

\begin{tabular}{|c|c|c|c|}
\hline Weakness & Agree (\%) & Disagree (\%) & Undecided (\%) \\
\hline 1. Low activities of extension agents & $64(77.1)$ & $15(18.1)$ & $4(4.8)$ \\
\hline $\begin{array}{l}\text { 2. Lack of effective supervision by the } \\
\text { government }\end{array}$ & $64(77.1)$ & 19(22.9) & - \\
\hline $\begin{array}{l}\text { 3. Illiteracy level of the dwellers around forest } \\
\text { reserve }\end{array}$ & $54(65.1)$ & $24(28.9)$ & $5(6.0)$ \\
\hline 4. Lack of Capital/ low income power among & $56(67.5)$ & $24(28.9)$ & $3(3.6)$ \\
\hline
\end{tabular}


the rural dwellers

5. Lack of co-operation and co-ordination 46(55.4) among the rural dwellers

6. Structure and belief of the environment

7. Too much access to forest reserve due to the satisfaction that government want to do for his people around forest reserve.

8. Problem of finance needed and monitoring of the implementation.

9. Inadequate information from the policy 50(60.2) 28(33.7) maker.

$\begin{array}{lll}48(57.8) & 30(36.1) & 5(6.0) \\ 46(55.4) & 28(33.7) & 9(10.8) \\ & & \\ 45(54.2) & 31(37.3) & 7(8.4) \\ 50(60.2) & 28(33.7) & 5(6.0)\end{array}$

$5(6.0)$

Source: Field Survey, 2019.

\section{Logit Regression Model for Forest Dwellers' Benefits from Onigambari Forest Reserve \\ The Binary Models \\ Binary Regression Models}

Binary regression models obtained for forest dwellers' benefits from Onigambari Forest Reserve (Table 3).

$B D F F=28.68+0.57 A R N-$

$$
\begin{aligned}
& \text { 6.90EIND - 0.25EFA - 0.88RRI + 0.14SRUM + } \\
& 0.63 E E G+3.16 E G-5.89 M L U C+ \\
& 8.35 A S F P-1.78 I I P-0.04 R M I-
\end{aligned}
$$

$\mathrm{N}=83$, Final loss $=0.00$, Chi-square $(\mathrm{df} ; 12)=95.99$.

Odd-ratio (Unit change). Constant (28.68); ARN (1.70), EIND (0.001), REL (O.14), EFA (0.78), RRI (0.41), SRUM (1.15), EEG (2.10), EG (23.50), MLUC (0.002), ASFP (62.18), IIP (0.17), RMI (0.960).

Where,

BDFF - Forest dwellers' Benefits from Onigambari Forest Reserve

ARN - Attention to Road Network

EIND - Establishment of Industries

REL - Rural Electrification

EFA - Efficient Forest Administration

RRI - Recruitment for Regular Inventory by the Government SRUM - Stem down of Rural-Urban Migration

EEG - Enhancement of Economic Growth.

EG - Employment Generation

MLUC - More Land Under Cover

ASFP - Achieving of Sustainable Forest Production IIP - Increase in Income Propensity of the dwellers
RMI - Raw Materials for Industries

Model presented above for Forest dwellers' benefits from Onigambari forest reserve gave overall significant fit to the data judging from ${ }_{\chi}^{2}$ Value that was significant at $\mathrm{p}<0.05$. Achievement of Sustainable Forest Production (ASFP) had the highest odd-ratio of 62.18 followed by Employment generation (EG) with the odd-ratio of 2.10 and lastly, Attention to Road Network (ARN) with the odd-ratio of 1.70 respectively.

Therefore, the significant benefits identified to be enjoyed by the forest dwellers in and around Onigambari forest reserve were Achievement of Sustainable Forest Production (ASFP) by the management of the forest which paved way for the continuous production of forest products and services which in turn affects the livelihood of the dwellers positively. Others are Employment Generation (EG), Enhancement of Economic Growth (EEG) in the area and Attention to Road Network (ARN) in the study area. There was sufficient evidence that the model were statistically significant. In other words, the higher the value of odds-ratio, the higher the level of significance of these benefits enjoyed by the forest dwellers in Onigambari forest reserve. Hence, it clearly indicated the variable (s) i.e benefits that mostly derived from the study area. The implication was corroborated by Deeks (1996); Bland and Altman (2000) that the logit model provides information on the consequence of one variable on the other. Therefore, identifying these benefits indicated that the existence of Onigambari forest reserve has impacted the livelihood of forest dwellers in the area. 
Table 3: Logit Binary Nature for Forest Dwellers' Benefits from Onigambari Forest Reserve

Dependent Variable $(B D F F)=$ Forest Dwellers' Benefits from Onigambari Forest Reserve $($ Yes $=1),($ No $=0)$

\begin{tabular}{|c|c|c|}
\hline Independent Variables & Coefficient & Odd-ratio \\
\hline $\begin{array}{l}\text { Whether (ARN) has been a benefit being derived from the } \\
\text { existence of the forest reserve. }\end{array}$ & 0.57 & $1.70^{*}$ \\
\hline $\begin{array}{l}\text { Whether (EIND) has been a benefit derived from the existence of } \\
\text { the forest reserve. }\end{array}$ & -6.9 & $0.001 \mathrm{~ns}$ \\
\hline $\begin{array}{l}\text { Whether (REL) has been a benefit being derived from the } \\
\text { existence of the forest reserve. }\end{array}$ & -1.94 & $0.14 \mathrm{~ns}$ \\
\hline $\begin{array}{l}\text { Whether (EFA) has been a benefit being derived from the } \\
\text { existence of the forest reserve. }\end{array}$ & -0.25 & $0.78 \mathrm{~ns}$ \\
\hline $\begin{array}{l}\text { Whether (RRI) has been a benefit being derived from the } \\
\text { existence of the forest reserve. }\end{array}$ & -0.88 & $0.41 \mathrm{~ns}$ \\
\hline $\begin{array}{l}\text { Whether (SRUM) has been a benefit being derived from the } \\
\text { existence of the forest reserve. }\end{array}$ & 0.14 & $1.15 \mathrm{~ns}$ \\
\hline $\begin{array}{l}\text { Whether (EEG) has been a benefit being derived from the } \\
\text { existence of the forest reserve. }\end{array}$ & 0.63 & $2.10^{*}$ \\
\hline $\begin{array}{l}\text { Whether (EG) has been a benefit being derived from the existence } \\
\text { of the forest reserve. }\end{array}$ & 3.16 & $23.50 *$ \\
\hline $\begin{array}{l}\text { Whether (MLUC) has been a benefit being derived from the } \\
\text { existence of the forest reserve. }\end{array}$ & -5.89 & $0.002 \mathrm{~ns}$ \\
\hline $\begin{array}{l}\text { Whether (ASFP) has been a benefit being derived from the } \\
\text { existence of the forest reserve. }\end{array}$ & 8.35 & $62.18^{*}$ \\
\hline $\begin{array}{l}\text { Whether (IIP) has been a benefit being derived from the existence } \\
\text { of the forest reserve. }\end{array}$ & -1.78 & $0.17 \mathrm{~ns}$ \\
\hline 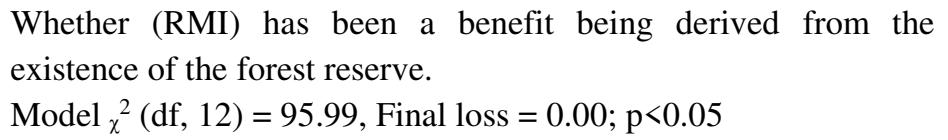 & -0.04 & $0.96 \mathrm{~ns}$ \\
\hline
\end{tabular}

$*=$ Significant at $\mathbf{p}<0.05 ;$ ns $=$ Not significant

\section{CONCLUSION AND RECOMMENDATION}

This study uphold the existence of weakness in enforcement of forest legislation in Onigambari forest reserve and found low activities of extension agents and lack of effective supervision by government (Managers) to be significantly responsible for weakness in enforcement of forest legislation in the area. The study also identified the various benefits being derived by the forest dwellers from the forest reserve due to the existence of forest legislation in the area to be achievement of sustainable forest production, employment generation, enhancement of economic growth in the area and attraction of attention to the road network in the study area. Therefore, building of institutional capacity to foster better enforcement of forest legislation and compliance is of paramount importance to achieving sustainable forest management in the reserve, such that more benefits can be enjoyed by the management of the reserve, forest dwellers and country at large.

\section{REFERENCES}

[1] Adejumo, A.A. (2016). Effects of Forest Policy Implementation on Forest Plantation Management in Nigeria. An Unpublished Ph.D Thesis Submitted to the Department of Forest Resources Management, University of Ibadan. Pp 141142.

[2] Adeyoju, S.K. (2001). Forestry for National Development: (Ed: Popoola, L; Abu, J.E. and Oni P.I). In the proceedings of the $27^{\text {th }}$ Annual Conference of Forestry Association of Nigeria held in Abuja, FCT, 17-21 ${ }^{\text {st }}$ Sept., 2001. Pp 55-67.

[3] Akinbile, L.A. (2007). Social Impact of Limestone Exploitation in Yewa North Local Government Area of Ogun State, Nigeria. Pakistan Journal of Social Science Vol. 1 (1), Pp. 107-111.

[4] Banjo, A.A. and Abu, J.E. (2014). Community Involvement in Forest Management. Proceedings of the $37^{\text {th }}$ annual 
conference of the Forestry Association of Nigeria, held in Minna, Niger State, Nigeria. $9^{\text {th }}-14^{\text {th }}$ November, 2014, 250251Pp.

[5] Bland, J.M. and Altman, D.G. (2000). "The Odds ratio" British Medical Journal 230, 1468.

[6] Calibre and SCC. (2000). Number of Forest-dependent People. In Feasibility Study for the UK Department for International Development of Forestry Research Programme. The Statistical Service Center, University of Reading, UK. $15 \mathrm{p}$.

[7] Davies, H.T.O., Crombie, I.K. and Tavakoli, M. (1998). When can Odd-Ratios Mislead? British Medical Journal 316: 989-991.

[8] Deeks, J. (1996). Swots Corner: What is an Odds Ratio? Bandolier, 3(3), Issue 25, 6-7.

[9] Diaw, K., Blay, D. and Adu-Anning, C. (2002). SocioEconomic Survey of Forest Fringe Communities: Krokosua Hills Forest Reserve. A report submitted to the Forestry Commission of Ghana. P86.

[10] FAO. (2010). Forest Law Enforcement (Forest Law Compliance and Governance). Rome- Italy. (http://www.fao.org/forestry/law/en/) Accessed 4 ${ }^{\text {th }}$ Nov. 2019.

[11] Faleyimu, O.I. (2010). Status of Forest Policy Implementation in South-West Nigeria. An Unpublished Ph.D Thesis Submitted to the Department of Forest Resources Management, University of Ibadan. Pp 13, 212-221.

[12] United State Department of Agriculture (USDA). (2015): Forest Service Law Enforcement and Investigations (http://www.fs.fed.us/lei). Accessed 6 ${ }^{\text {th }}$ November, 2019. 1p. 